\title{
Increased protoporphyrin in erythrocytes in a child with acute intermittent porphyria
}

\author{
ANITA GREGOR, EWA KOSTRZEWSKA, HALINA PROKURAT, ZOFIA PUCEK, AND \\ EMILIA TORBICKA
}

From the Department of Surgery, Institute of Haematology; and Department of Infant Diseases, Municipal Paediatric Hospital, Warsaw, Poland

SUMMARY A child is described with acute intermittent porphyria but having an erythropoietic component, with disordered metabolism of porphyrins in bone marrow.

Many cases of porphyria are encountered which do not fall into the present classifications. The justification for classifying porphyrias into erythropoietic and hepatic forms, based on the site of the metabolic abnormality, was put in doubt when disorders of porphyrin biosynthesis were found to occur in both bone marrow and liver in the same case (Schmid et al., 1954; Scholnick et al., 1971; Nicholson et al., 1973; Wolff et al., 1975).

The case presented here is one of acute intermittent porphyria according to the biochemical and genetic findings. Nevertheless, large amounts of protoporphyrin were present in the erythrocytes, which is not described in acute intermittent porphyria.

\section{Case report}

A 6-month-old girl was admitted with convulsions. She was seriously ill, unconscious, heart rate 200/ $\mathrm{min}$, and with hepatosplenomegaly. Her psychomotor development was retarded, with weakness especially of the lower extremities, and she was unable to hold up her head. Bilateral congenital cataracts were present. From birth she had been passing pink urine.

From the age of 6 months until her death at 22 months she was admitted several times with convulsions, and on different occasions subdural haematoma, urinary tract infection, and pneumonia were found. It was observed that phenobarbitone administed for controlling convulsions led to increased convulsions, with deterioration of her general condition, and to more obvious pink colouration of the urine. Similar effects were produced by infections.

Received 31 March 1977
A mild hypochromic anaemia was noted $(\mathrm{Hb}$ 9.6-11 g/dl); reticulocytes ranged from 10 to $25 \%$; serum iron $120 \mu \mathrm{g} / 100 \mathrm{ml}(21 \cdot 5 \mu \mathrm{mol} / \mathrm{l})$. Hypersensitivity to light or other skin changes were never observed. Examination of the teeth at 10 months showed no discoloration or fluorescence.

\section{Methods}

Protoporphyrin in the erythrocytes was determined by the method of Heilmeyer (1964), urinary and faecal porphyrins by the method of Rimington (1961), porphobilinogen and $\delta$-aminolaevulinic acid in urine by the method of Mauzerall and Granick (1956). Porphyrins and their precursors in the subdural fluid were estimated as in urine. Esterification and separation of methyl esters of porphyrins in stool and urine were carried out by the methods described by Doss (1969). Jensen's (1963) method was used for separation of I and III coproporphyrin isomers. The activity of the uroporphyrinogen synthetase was determined according to Magnussen et al. (1974).

\section{Results}

A raised level of urinary porphobilinogen was found (Table 1) and indicated a diagnosis of acute intermittent porphyria. An increased level of uroporphyrin was found and accounted for $82 \%$ of all porphyrins excreted in the urine (Table 2). The proportion of isomer-III of coproporphyrin may be related to acute intermittent porphyria (AIP), though this proportion was below that typically found in AIP.

With a view to confirming the diagnosis of AIP, the family was studied (Table 3 ; Fig.). The results indicate that AIP was inherited from the mother. This was confirmed by observing that in the mother's 
948 Gregor, Kostrzewska, Prokurat, Pucek, and Torbicka

Table 1 Porphyrin precursors: porphobilinogen (Pbg), $\delta$-aminolaevulinic acid $(A L A)$, and porphyrins in urine

\begin{tabular}{|c|c|c|c|c|c|}
\hline $\begin{array}{l}\text { Age } \\
(m)\end{array}$ & $\begin{array}{l}P b g \\
(m g / 24 h)\end{array}$ & $\begin{array}{l}A L A \\
(m g / 24 h)\end{array}$ & $\begin{array}{l}\text { Coproporphyrin } \\
(\mu g / 24 h)\end{array}$ & $\begin{array}{l}\text { Uroporphyrin } \\
(\mu g / 24 h)\end{array}$ & $\begin{array}{l}\text { Urine } \\
(m l / 24 h)\end{array}$ \\
\hline $\begin{array}{l}6 \\
9 \\
11 \cdot 5 \\
12 \\
13\end{array}$ & $\begin{array}{r}10 \cdot 1 \\
5 \cdot 4 \\
22 \cdot 2 \\
21 \cdot 8 \\
20 \cdot 1\end{array}$ & $\begin{array}{l}2 \cdot 5 \\
0 \cdot 5 \\
2 \cdot 5 \\
2 \cdot 6 \\
4 \cdot 6\end{array}$ & $\begin{array}{l}31 \cdot 2 \\
29 \cdot 6 \\
39 \cdot 0 \\
35 \cdot 4 \\
49 \cdot 0\end{array}$ & $\begin{array}{r}86 \cdot 2 \\
261 \cdot 5 \\
175 \cdot 0 \\
154 \cdot 0 \\
185 \cdot 0\end{array}$ & $\begin{array}{l}400 \\
450 \\
770 \\
240 \\
325\end{array}$ \\
\hline $\begin{array}{l}\text { Normal } \\
\text { (Käser et al., 1963) } \\
\text { Normal (!l) } \\
\quad \text { (Beauvais et al., } \\
\text { 1976) }\end{array}$ & $\begin{array}{l}0.075-0.37 \\
\pm 0.055 \\
\leqslant 2\end{array}$ & $\begin{array}{l}0 \cdot 125-0 \cdot 7 \\
\pm 0 \cdot 092 \mathrm{SD} \\
\leqslant 3\end{array}$ & $<250$ & 0 & \\
\hline $\begin{array}{l}\text { Normal* }(/ 1) \\
\text { (authors) }\end{array}$ & $\begin{array}{l}1 \cdot 14 \\
\pm 0.67 \mathrm{SD}\end{array}$ & $\begin{array}{l}2 \cdot 42 \\
\pm 1 \cdot 5 \mathrm{SD}\end{array}$ & $<100$ & $<35$ & \\
\hline
\end{tabular}

*Authors' normal values established in 20 healthy children aged 1-2 years.

Table 2 Urinary porphyrins determined by separation of their methyl esters and thin-layer chromatography

\begin{tabular}{lccl}
\hline Porphyrin type & $\mu g / 24 h$ & $\%$ & $\%$ of isomer-III \\
\hline 4 COOH & 6.0 & 5.63 & 62.4 \\
5 COOH & 6.8 & 6.38 & \\
6 COOH & 1.0 & 0.94 & \\
7 COOH & 5.3 & 4.98 & \\
8 COOH & 87.4 & 82.06 & \\
\hline
\end{tabular}

Table 3 Urine investigations in the family

\begin{tabular}{|c|c|c|c|c|}
\hline & $\begin{array}{l}\mathrm{Pbg} \\
(m g / 24 h)\end{array}$ & $\begin{array}{l}A L A \\
(m g / 24 h)\end{array}$ & $\begin{array}{l}\text { Copro- } \\
\text { porphyrin } \\
(\mu g / 24 h)\end{array}$ & $\begin{array}{l}\text { Uropor- } \\
\text { phyrin } \\
(\mu g / 24 h)\end{array}$ \\
\hline $\begin{array}{c}\text { Mother } \\
1 \\
2 \\
3 \\
4\end{array}$ & $\begin{array}{r}4 \cdot 0 \\
14 \cdot 9 \\
3 \cdot 4 \\
4 \cdot 4\end{array}$ & $\begin{array}{l}5 \cdot 3 \\
2 \cdot 1 \\
2 \cdot 6 \\
5 \cdot 0\end{array}$ & $\begin{array}{l}221 \cdot 0 \\
287 \cdot 0 \\
166 \cdot 0 \\
196 \cdot 9\end{array}$ & $\begin{array}{c}26 \cdot 0 \\
187 \cdot 0 \\
0 \\
0\end{array}$ \\
\hline Mother's sister I & $1 \cdot 3$ & $4 \cdot 1$ & $63 \cdot 7$ & 0 \\
\hline $\begin{array}{l}\text { Mother's sister II } \\
1 \\
2\end{array}$ & $\begin{array}{l}5.0 \\
2.6\end{array}$ & $\begin{array}{l}2 \cdot 8 \\
4.0\end{array}$ & $\begin{array}{l}294 \cdot 0 \\
258 \cdot 0\end{array}$ & $\begin{array}{l}\mathbf{0} \\
\mathbf{0}\end{array}$ \\
\hline $\begin{array}{l}\text { Mother's brother } \\
1 \\
2\end{array}$ & $\begin{array}{l}2 \cdot 4 \\
3 \cdot 2\end{array}$ & $\begin{array}{l}2 \cdot 4 \\
4 \cdot 4\end{array}$ & $\begin{array}{l}226 \cdot 0 \\
138 \cdot 0\end{array}$ & $\begin{array}{l}1.9 \\
7.6\end{array}$ \\
\hline $\begin{array}{l}\text { Grandmother } \\
\text { (maternal) }\end{array}$ & $5 \cdot 0$ & $4 \cdot 2$ & 206.0 & $17 \cdot 0$ \\
\hline $\begin{array}{c}\text { Father } \\
1 \\
2 \\
3\end{array}$ & $\begin{array}{l}0 \\
6 \cdot 2 \\
1 \cdot 8\end{array}$ & $\begin{array}{l}3.9 \\
0.7 \\
2.6\end{array}$ & $\begin{array}{r}63 \cdot 0 \\
106.0 \\
125 \cdot 0\end{array}$ & $\begin{array}{l}0 \\
49 \cdot 0 \\
0\end{array}$ \\
\hline $\begin{array}{c}\text { Grandfather } \\
\text { (paternal) } \\
1 \\
2\end{array}$ & $\begin{array}{l}2 \cdot 1 \\
3 \cdot 2\end{array}$ & $\begin{array}{l}1.9 \\
4.7\end{array}$ & $\begin{array}{l}131 \cdot 0 \\
147.0\end{array}$ & $\begin{array}{l}\mathbf{0} \\
\mathbf{0}\end{array}$ \\
\hline
\end{tabular}

erythrocytes the activity of urosynthetase was decreased; $14.7 \mathrm{nmol}$ porphyrins produced per $\mathrm{ml}$ erythrocytes per hour. The high level of porphobilinogen ( $\mathrm{Pbg}$ ) found on a single occasion in the

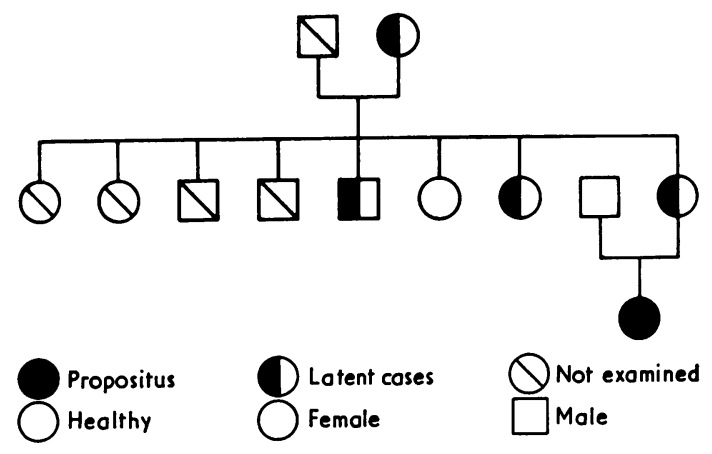

Fig. Family tree. Note: 4 sibs of the mother died in early childhood and were not examined.

father, and the slightly raised $\mathrm{Pbg}$ level in the grandfather are difficult to explain, and unfortunately these relatives did not allow further studies for urosynthetase activity. No clinical manifestations of porphyria were noted in any members of the family.

The level of protoporphyrin was much raised in the patient's erythrocytes (Table 4), while the level of coproporphyrin was only slightly so (Table 5). In the earlier stages of the disease no abnormality was observed in faecal excretion of porphyrins, but later it increased to $55.7 \mu \mathrm{g} / \mathrm{g}$ dry weight. Coproporphyrin accounted for $69 \%$ of all porphyrins excreted, and it was present mainly in the form of isomer-I. In

Table 4 Coproporphyrins and protoporphyrins in erythrocytes and faeces of patient

\begin{tabular}{|c|c|c|c|c|}
\hline \multirow{2}{*}{$\begin{array}{l}\text { Age } \\
\text { (m) }\end{array}$} & \multicolumn{2}{|c|}{ Erythrocytes $(\mu \mathrm{g} / 100 \mathrm{ml})$} & \multicolumn{2}{|c|}{ Faeces $(\mu g / g$ of dry weight) } \\
\hline & Copro & Proto & Copro & Proto \\
\hline $\begin{array}{l}6 \\
9 \\
11 \cdot 5 \\
\text { Normal }\end{array}$ & $\begin{array}{l}50 \cdot 2 \\
15 \cdot 8 \\
0 \cdot 5-2 \cdot 7\end{array}$ & $\begin{array}{c}1123 \cdot 0 \\
872 \cdot 6 \\
22-175^{*}\end{array}$ & $\begin{array}{c}13 \cdot 8 \\
0-14\end{array}$ & $\begin{array}{l}2 \cdot 3 \\
5 \cdot 7 \\
5-51 t\end{array}$ \\
\hline
\end{tabular}

*Aldrich et al. (1955). †Chisholm (1964). 
Table 5 Faecal porphyrins separated by thin-layer chromatography in patient at 16 months

\begin{tabular}{lccl}
\hline $\begin{array}{l}\text { Porphyrin } \\
\text { type }\end{array}$ & $\begin{array}{l}\mu \mathrm{g} / \mathrm{g} d r y \\
\text { weight }\end{array}$ & $\%$ & $\%$ of isomer-III \\
\hline $2 \mathrm{COOH}$ & 5.52 & 6.83 & \\
$4 \mathrm{COOH}$ & 55.7 & 68.9 & 7.8 \\
5 COOH & trace & & \\
$6 \mathrm{COOH}$ & trace & & \\
7 COOH & trace & 16.21 & \\
$8 \mathrm{COOH}$ & 13.1 & 8.04 & \\
X & 6.5 & & \\
\hline
\end{tabular}

healthy subjects coproporphyrin isomer-III accounts for about $90 \%$ of the excreted coproporphyrin. No rise in porphyrin content of erythrocytes and faeces was observed in the members of the family investigated. In the cerebrospinal fluid (Table 6) obtained from the subdural hygroma, slight amounts of porphyrin precursors, and a high level of uroporphyrin were found.

Table 6 Porphyrins and their precursors in subdural fluid in patient at 9 months

\begin{tabular}{llll}
\hline Pbg $(m g / l)$ & $A L A(m g / l)$ & $\begin{array}{l}\text { Coproporphyrin } \\
(\mu g / l)\end{array}$ & $\begin{array}{l}\text { Uroporphyrin } \\
(\mu \mathrm{g} / l)\end{array}$ \\
\hline 2.02 & 0.24 & 21.7 & 374.4 \\
\hline
\end{tabular}

\section{Discussion}

The diagnosis of AIP, rarely seen in small children (Beauvais et al., 1976), was based on clinical suspicions and the results of biochemical and genetic investigations. This diagnosis was suggested by convulsions, paresis of muscles, tachycardia, pink urine, and worsening of the general condition with passage of darker urine after phenobarbitone and during infections. But the increased level of protoporphyrin in erythrocytes and the presence of coproporphyrin isomer-I in the faeces are not known to occur in AIP. Various forms of porphyria with atypical biochemical patterns have been reported by Hofstad et al. (1973), Rimington and With (1973), Eriksen and Eriksen (1974), and Tschudy (1974), but we know of no case with the findings of ours. A large increase in protoporphyrin in the erythrocytes and the presence of coproporphyrin isomer-I may suggest disturbances of porphyrin synthesis in bone marrow paralleling similar disturbances of synthesis in the liver. It has been suggested that porphyrin metabolism may be disturbed in both bone marrow and liver in erythropoietic porphyria, but in this condition increased urinary porphobilinogen excretion has never been observed (Gray et al., 1964; Goldberg, 1968; Scholnick et al., 1971; Nicholson et al., 1973; Wolff et al., 1975).

The high uroporphyrin content of the subdural fluid remains to be explained. Raised levels of por- phyrin precursors in the cerebrospinal fluid have been observed during attacks of AIP (Bonkowsky et al., 1971) and increased levels of porphyrins in porphyria cutanea tarda (Filippini and Simmler, 1973).

The result in our case suggest that there was disordered porphyrin synthesis in the bone marrow together with the characteristic abnormalities found in acute intermittent porphyria.

Supported by Polish Academy of Science Project no. 09.7.4.1.10.

\section{References}

Aldrich, R. A., Labbe, R. F., and Talman, E. L. (1955). A review of porphyrin metabolism with special reference to childhood. American Journal of the Medical Sciences, 230, 675-697.

Beauvais, P., Klein, M. L., Denave, L., and Martel, C. (1976). Porphyrie aigue intermittente à l'age de quatre mois. Archives Françaises de Pédiatrie, 33, 987-992.

Bonkowsky, H. L., Tschudy, D. P., Collins, A., Doherty, J., Bossenmaier, I., Cardinal, R., and Watson, C. J. (1971). Repression of the overproduction of porphyrin precursors in acute intermittent porphyria by intravenous infusions of hematin. Proceedings of the National Academy of Sciences of the USA, 68, 2725-2729.

Chisolm, J. J., Jr. (1964). Pediatric aspects of the porphyrias. Journal of Pediatrics, 64, 159-172.

Doss, M. (1969). Trennung, Isolierung und Bestimmung von Proto-, Kopro-, Pentacarboxy-, Hexacarboxy-, Heptacarboxy-und Uroporphyrin. Hoppe-Seylers Zeitschrift für Physiologische Chemie, 350, 499-502.

Eriksen, L., and Eriksen, N. (1974). Porphyrin distribution and porphyrin excretion in human congenital erythropoietic porphyria. Scandinavian Journal of Clinical and Laboratory Investigation, 33, 323-332.

Filippini, L., and Simmler, F. (1973). Porphyrinnachweis im Liquor cerebrospinalis bei chronischer hepatischer Porphyrie. Deutsche Medizinische Wochenschrift, 98, 513-514.

Goldberg, A. (1968). Diagnosis and treatment of the porphyrias. Proceedings of the Royal Society of Medicine, 61, 193-196.

Gray, C. H., Kulczycka, A., Nicholson, D. C., Magnus, I. A., and Rimington, C. (1964). Isotope studies in a case of erythropoietic protoporphyria. Clinical Science, 26, 7-15.

Heilmeyer, L. (1964). Die Störungen der Bluthämsynthese. Thieme, Stuttgart.

Hofstad, F., Seip, M., and Ericksen, L. (1973). Congenital erythropoietic porphyria with a hitherto undescribed porphyria pattern. Acta Paediatrica Scandinavica, 62, 380-384.

Jensen, J. (1963). Separation of the coproporphyrin isomers I and III by thin layer chromatography. Journal of Chromatography, 10, 236-238.

Käser, H., Koblet, H., and Riva, G. (1963). Die Ausscheidung von Porphyrinpräkursoren im Urin bei Kindern verschiedenen Lebensalters. Schweizerische Medizinische Wochenschrift, 93, 1052-1057.

Magnussen, C. R., Levine, J. B., Doherty J. M., Cheesman, J. O., and Tschudy, D. P. (1974). A red cell enzyme method for the diagnosis of acute intermittent porphyria. Blood, 44, 857-868.

Mauzerall, D., and Granick, S. (1956). The occurrence and determination of $\delta$-aminolevulinic acid and porphobilinogen in urine. Journal of Biological Chemistry, 219, 435-448. 
Nicholson, D. C., Cowger, M. L., Kalivas, J., Thompson, R. P. H., and Gray, C. H. (1973). Isotopic studies of the erythropoietic and hepatic components of congenital porphyria and 'erythropioetic' protoporphyria. Clinical Science, 44, 135-150.

Rimington, C. (1961). Quantitative Determination of Porphobilinogen and Porphyrins in Urine and Faeces. Broadsheet No. 36. Association of Clinical Pathologists, London.

Rimington, C., and With, T. K. (1973). Porphyrin studies in congenital erythropoietic porphyria. Danish Medical Bulletin, 20, 5-12.

Schmid, R., Schwartz, S., and Watson, C. J. (1954). Porphyrin content of bone marrow and liver in the various forms of porphyria. Archives of Internal Medicine, 93, 167-190.
Scholnick, P., Marver, H. S., and Schmid, R. (1971). Erythropoietic protoporphyria: evidence for ultiplem sites of excess protoporphyrin formation. Journal of Clinical Investigation, 50, 203-207.

Tschudy, D. P. (1974). Porphyrin metabolism and the porphyrias. Duncan's Diseases of Metabolism, 7th ed., Chap. 12. Ed. by P. K. Bondy and L. E. Rosenberg. Saunders, Philadelphia.

Wolff, K., Wolff-Schreiner, E., and Gschnait, F. (1975). Liver inclusions in erythropoietic protoporphyria. European Journal of Clinical Investigation, 5, 21-26.

Correspondence to Prof. E. Kostrzewska, Institute of Haematology, Research Laboratory, Chocimska Street 5, 00-957 Warsaw, Poland. 